growth, geographic proximity (on an individual state level), importance to trade, and resource wealth.

\section{CONCLUSIONS}

This research has obvious limitation and weaknesses. Graphs are not as reliable as regressions and other more advance statistical analysis when identifying trends in the data, but the data limited the types of analyses possible. The relationships this study was able to propose were tenuous and need additional confirmation The availability of data was another significan issue. The sample size was not large enough, and it was limited further by the five year gaps between diplomatic data, lack of curren diplomatic data, and lack of older GDP data, the number of conclusions a researcher would be able to draw were limited.

Despite limitations it should not be assumed that the research was unsuccessful. To the contrary, research seems to suggest US no longer consider poor states gaining increased credit access through IDA graduation to be a noteworthy event. This research demonstrates that the United States instead takes into accoun a variety of different factors when attributing higher status to states. It is significant that many of the relevant factors are related to economics; this shows that while the United States may not be responding directly to IDA graduation, financial development does play a role in increased status in the American perspective.

Opportunities for further research are numerous. It would be very interesting and useful to perform the same study using a more advanced statistical analysis unlimited by data concerns. This would demonstrate with more certainty the correlations between access to credit and increased internationa status. Another opportunity for study concerns further relationships between diplomatic exchanges and financial growth. Of all the factors motivating diplomatic relationships and the changes within, how large of a factor

\title{
WOMEN OF WAR
}

The Female Fighters of the LIBERATION TIGERS OF TAMIL EELAM

\section{INTRODUCT I ON}

S War in 1983, Tamil women have occupied a key role in the conflict. In the struggle for the anticipated state of Tamil Eelam, the socio-cultural role of women underwent, and continues to undergo, a radical transformation. As a result of this "gendered reconstruction of womanhood," women are no longer constrained to the household during times of war, but instead, frequently venture out into the battlefields, sideby-side with their male combatant counterparts. Looking back at the 26-year-long battle between the Liberation Tigers of Tamil Eelam (LTTE) and the Sri Lankan state, one can see that women do indeed play a vital role in times of violent conflict. The question remains, however, whether the female LTTE combatants have been manipulated into becoming victims of war by the male-dominated insurgency, or whether they have become agents of their own empowerment through their participation in the conflict.

This paper explores the gendered dimensions of ethnic conflict, with a focus on the role that women have played in the LTTE I analyze the gendered reconstruction of Tami women in war to determine whether their participation in violence has altered their selfperception and, to a lesser extent, society's view of female combatants. My analysis is based on
ERIN ALEXANDER Yale University many sources that offer first-hand knowledge of, and interviews with, female LTTE fighters.

In order to better understand the roots of the conflict between the Tamil and Sinhalese peoples of Sri Lanka, Section II first provides a brief history of the Sri Lankan Civil War, leading up to the rise of the LTTE during the 1983 to 2009 time period. Part III outlines the LTTE's role in the war, and how it transformed socio-cultural norms in Sri Lanka by mobilizing Tamil women to fight. Next, Part IV focuses on the subsequent effects that mobilization of female combatants had on society and, more importantly, on the women involved in the conflict. I will examine how female sentiments were manifested in either a positive, self-empowering light, or a negative, victimized manner. Finally, the conclusion of the paper looks at ex-LTTE female fighters in today's Tamil society. While the recruitment of female combatants by the LTTE has been perceived by many to be an act of victimization by the male leaders of the conflict, I believe that this new role for women serves as a potential means of self-empowerment through defying societal, socio-cultural norms.

HISTORICAL BACKGROUND AND THE RISE OF THE LIBERATION TIGERS OF TAMIL EELAM

As a consequence of European 
imperialism and internal ethnic fragmentation, greater autonomy, and the idea of establishing a Sri Lanka has experienced a relentless string of Tamil Eelam became more and more appealing conflicts over the reclamation of its land. Since to them. The newly founded Sinhalese the sixteenth century, Sri Lanka has been an government quickly began disenfranchising the object of European desire and possession. In previously politically privileged Tamil people, 1505, the Portuguese colonized the island and creating a mode of political representation divided it into seven warring factions. Nearly a based on the majority ethnic political parties. ${ }^{5}$ century later, the Dutch arrived and began ruling Sinhalese candidates began running on the Sinhalese and Tamil kingdoms, falling short platforms of "Sinhalese-only," promising of capturing the prized Kandyan kingdom (see to "restore Buddhism to its proper place in Appendix A). Upon the British arrival in 1815, society." These political tactics appealed to the Kingdom of Kandy was finally seized and the masses, and Sinhalese electoral victories the island was eventually politically "unified." affirmed Tamil perceptions that they were However, a truly unified nation was never the true minority in the hands of the Sinhala achieved. $^{3}$

Britain's preferential treatment of the minority Tamil ethnic group over the larger ethnic Sinhalese population only served to exacerbate existing tensions. Since the beginning of British rule over Sri Lanka in 1815, the Tamils, who made up 22 percent of the Sri Lankan population, had disproportionate access to English education and civil services. ${ }^{4}$ Despite the post-colonial attempts to address and rectify the disparities among ethnic groups, the psychological legacy of colonial oppression led Tamils to continue viewing themselves as rightful but oppressed occupants of their homeland.

Following Sri Lanka's independence in 1948, the Tamil people started to push for the true minority in the hands of the Sinhala
majority. It quickly became apparent that bureaucratic methods of secession, such as the system of District Development Councils, would not prove acceptable to the Tamils. Resentment intensified, and in 1975 a young, radical Tamil named Veupillai Prabhakaran shot and killed the moderate Tamil mayor of Jaffna. This one action ultimately set in motion what was to follow: the Tamils' relentless and bloody fight for autonomy - bypassing all means of diplomacy or negotiated settlements.

Prabhakaran's assassination of the mayor of Jaffna was only the beginning in his ultimate ambition to achieve a separatist Tamil state. Just one year later, in 1976, Prabhakaran pioneered the use of suicide bombers, disguised in black uniforms with their heads masked and known to many as the "Black Tigers."8 On July 24, 1983, the Tigers killed thirteen soldiers in a landmine ambush; in turn, the Sinhalese made the Tamil population at large pay for the mistake. A murderous rampage ensued across the southern part of the island as the Sinhalese killed, tortured, and raped thousands of Tamil people. ${ }^{9}$

The killings were perhaps the worst ever anti-Tamil riots to date. Evidence shows that government ministers disclosed private voter registration to their "thug groups" in order to intimidate and, in some cases, assault Tamil residents; such instances pointed to the government's involvement with and support of these events. ${ }^{10}$ When the government finally addressed the media regarding the mass killings, they blamed the fighting on the "cumulative indignation of the Sinhalese people."11 This gross lack of concern and subsequential absence of remedying action convinced even the previously moderate Tamil people that, perhaps, the LTTE were right to be fighting for a separate homeland-independent from what they increasingly perceived as an unresponsive and corrupt Sri Lankan government. It was in this state of civil war that women had the choice to either be actively involved in the conflict, or risk becoming passive subjects of the war's violence.

\section{Female Mobilization}

From the outset of the formation of the LTTE, women contributed greatly to the military struggle against the Sri Lankan state and became involved in the "very instrument of militancy used to attain the political cause of liberation." 12 Social dynamics rooted in the state's repression of the Tamils attracted a significant number of Tamil women to the LTTE movement. The very tenets of the Women's Front, the all-female division inside the LTTE, were constructed around the concept of gender equality and the transformation of the gender status quo. The aims of the Women's Front were to "(i) secure the right of self-determination of 'Tamililam' and establish an independent democratic state of Tamililam; (ii.) abolish oppressive caste discrimination and division and feudal customs such as the dowry system; (iii.) eliminate all discrimination, secure social, political, and economic equality." ${ }^{13}$ The LTTE's proposal of these doctrines spoke to Tamil women and their desire for a more equal society, in which they could achieve everything that their male counterparts could attain

Similarly, the LTTE's propaganda appealed to the women who wished to simultaneously better their Tamil nation and to empower themselves. Posters depicting dynamic, militarized female bodies proclaimed, 


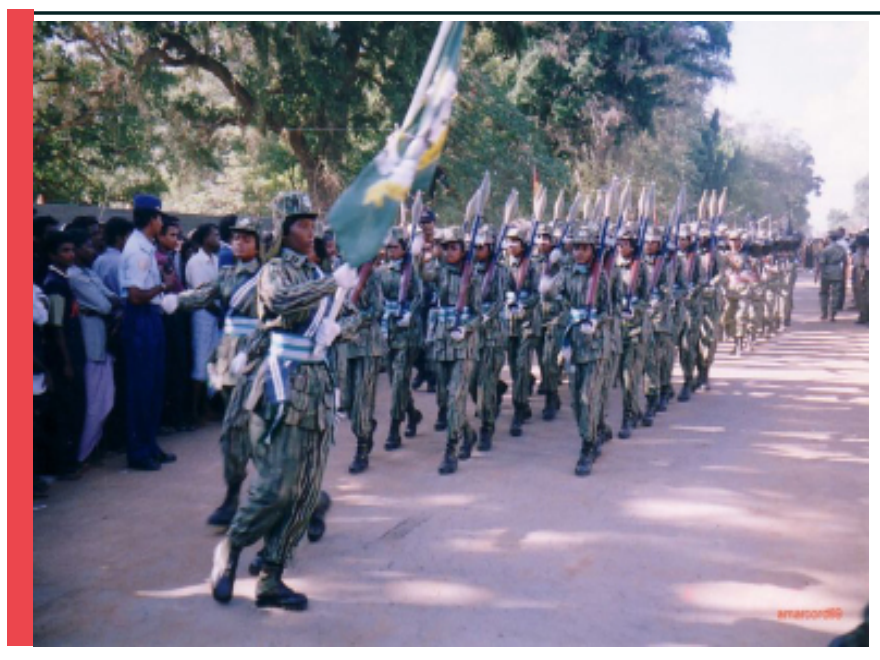

THE LTTE'S FEMALE WING MARCHING IN A PARADE, SHOWING THE ACTIVE FEMALE PARTICIPATION IN THE WAR AS COMBATANTS

"Woman you light the flames of liberation! traditional Tamil woman is circumscribed by the We are calling upon you Pick up the torch of "social expectations and cultural conventions liberation and struggle for with each heartbeat, of addaccam (modesty and silence) and our nation is taking form-Tamil Eelam!" 14 The odduccam (poise and restraint)." Her mobility LTTE propagated equal rights for women from is monitored and controlled in public spaces the very start of their campaign, declaring that it and she is constantly under the scrutiny of the was the only way to ensure female emancipation, male population. ${ }^{19}$ In fact, when Tamil men while simultaneously working towards an were interviewed regarding the gender norms autonomous homeland. ${ }^{15}$ The LTTE propaganda of Sri Lanka, they all acknowledged a woman's of "Tamil Liberation," for example, enabled the "lack of freedom and power."20 Traditional construction of female militants who could fight constructions of gender identity were incredibly for their nation and for themselves. ${ }^{16}$ Thus, the entrenched in Tamil society and in the "general LTTE's various recruitment tactics all sought to socialization processes." It appears as though

mobilize the female Tamil population in hopes the war has been the only means of transforming of reaching their ultimate goal of autonomy.

WOMEN IN TAMIL SOCIETY AND THE LTTE

Militarization subsequently shaped the identity of these "female fighters" in their own eyes as well as in those of the society. The LTTE's recruitment of women impelled the subsequent reconstruction of the Tamil woman from the "traditional ideal of the auspicious, fecund wife to the androgynous Armed Virgin." 17 Prior to the LTTE's recruitment of female soldiers, women were often confined to the domestic sphere; they were "generally respected, but simultaneously ambivalent, and [given a] somewhat restricted status." 18 The
Numerous first-hand accounts from female LTTE soldiers emphasize the sociocultural transformation that has stemmed from the war. Tamilini, a former LTTE frontranking soldier, recounts: "Tamil women are traditionally shy and timid, lacking selfconfidence. But all that changed after [LTTE] women were inducted into the battlefield." ${ }^{21}$ The previously omnipresent notion that femininity is directly connected with passivity, indecision, softness, and emotionality, while masculinity is associated with aggression, independence, rationality, and activity, is no longer accepted by the majority of Tamil society. ${ }^{22}$ The civil war has changed these norms for many Tamils, these fundamental traditions. and women have started to embrace their new
FROM THE MOVEMENT'S INCEPTION IN 1983, THE LTTE HAS DRAWN TENS OF THOUSANDS OF WOMEN INTO ITS RANKS, TRANSFORMING THE CONCEPT OF THE IDEAL TAMIL WOMAN INTO ONE WHO IS MILITARIZED, INDEPENDENT, AND EMPOWERED identity. For many of the female soldiers, their experiences of femininity were forever forever transformed.

The following section explains how the changes came about. I classify these transformative experiences in two overarching categories: empowerment and victimization. However, it is important to recognize the spectrum within the classification that inherently exists for female combatants. While it is difficult to characterize an individual as being either a victim or an active agent, I speak to the degree of victimization and empowerment as perceived by the combatants themselves.

WHAT IS THE NORM AND HOW ARE WOMEN DEFYING IT? WOMEN AS AGENTS OF SELF-EMPOWERMENT

From the movement's inception in 1983 the LTTE drew tens of thousands of women into its ranks, transforming traditional concepts of the ideal Tamil woman into one who is militarized, independent, and empowered. Drawing parallels between these ideas, I argue that Tamil women who empowered themselves through "gaining control or authority over some aspects of their lives in society" often did so by means of militarization. ${ }^{23}$ The LTTE's creation of the word Ah-lu-mai (empowerment) speaks to this very connection. Prior to this, there was no definition of empowerment in the Tamil language that related specifically to the recognition of the power that women have over their own lives. Ah-lu-mai, is thus, a reflection of the Tamil women's newly recognized "governance, authority, and leadership" roles. ${ }^{24}$

For some female fighters, violence was a means of survival, a means of "communicating resistance and the integrity of a struggle for selfdetermination to the Sri Lankan army". ${ }^{25}$ When Yamuna Sangarasivam asked Kala, a 23-yearold women cadre, why she joined the LTTE movement, she said:

When we see our sisters, and mothers raped by the [Sri Lankan] army, when we see our brothers taken away, beaten, and killed, when we watch our homes burn up in flames in the aftermath of aerial bombardments, what are we to do? Where do we go to hide, to live? I decided that I was not going to let that happen to me. I was not going to be raped and killed in the hands of the [Sri Lankan] army. I saw the courage of other girls who were joining the movement and decided that this was really the only way to survive. ${ }^{26}$

Many women like Kala joined to preempt rape by Sinhalese or Indian soldiers at the start of the war in the 1980's. Others joined because they had been personally victimized by the Sri Lankan army. ${ }^{27}$ After just a few years, it became clear that women could indeed achieve emancipation by mobilizing themselves in 
REFUGEES WHO WERE DISPLACED

BY THE BOMBINGS OF THE

GOVERNMENT. THE SUFFERING

OF THESE WOMEN AND THEIR

CHILDREN LED SOME TO JOIN

THE RANKS TO THE TAMIL

TIGERS.

support of the liberation organization. "They gained confidence, courage, determination, and in turn, are transformed from vulnerable targets into true revolutionaries". ${ }^{28}$ These women's livelihoods and very survival might have been in jeopardy without the self-confidence and skills that the LTTE provided them with.

Other women joined the movement in hopes of enacting societal change and eliminating the traditional gendered division in society. Rajini Thiranagama, a deceased Tamil feminist and human rights activist, wrote:

Women have come out strong during the war ... they have stood out as individuals or as small groups exposing atrocities and violations of dignity. ...Women who in the midst of war pleaded and argued with the militants for their families and the whole nations ... women's history does have a triumph. There is powerlessness, disappointment, and disillusion, but also hope. $^{29}$

Groups such as the Women's Military Wing and Birds of Paradise accounted for 30\% of the militants in the LTTE in the beginning of 1990, and aimed to break free of conservative gender roles and resist state oppression. ${ }^{30}$ Just as Thiranagama had anticipated, periods of conflict such as the Sri Lankan Civil War "open up spaces of agency for women to cross private/public barriers and to assume new roles

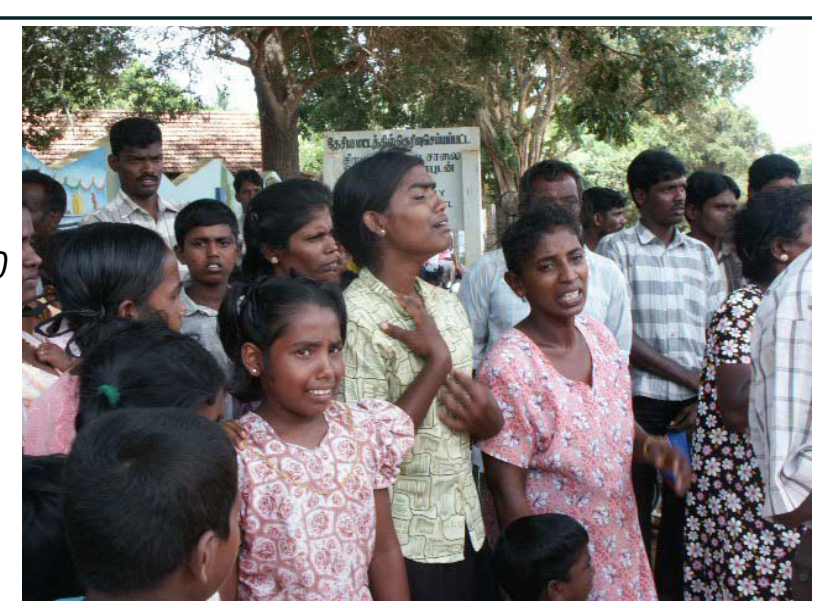

thereby shifting cultural norms to allow for the mobilization of female fighters". ${ }^{31}$ Thus, the war provided some women - who previously may not have had the opportunity to escape the private sphere - with the chance to not only change their own lives, but also to alter societal gender norms.

The following vivid account of LTTE female cadres effectively describes how the LTTE's mobilization of female soldiers inspired the empowerment of countless women. Thiranagama observes:

One cannot but be inspired when one sees the women of the LTTE in the night with their AKs slung over the shoulder ... One cannot but admire the dedication and toughness of their training ... One could see the nationalist fervor and the romantic vision of women in arms defending the nation (De Mel, 206). ${ }^{32}$

These women become agents of their own destinies through the militarization of their bodies and corresponding transformation of their identities.

Finally, some women cited the realization of an autonomous state of Tamil Eelam and the liberation of the Tamil people as their primary motivation for joining the LTTE movement. At the same time, many still also attained personal liberation through their active participation in the conflict. In Margaret Trawick's interview
IT IS PARTICULARLY CLEAR,

IF WE LOOK AT FIRST -

HAND ACCOUNTS OF FEMALE

SOLDIERS, THAT THESE WOMEN

HAD ENVISIONED A TAMIL

EMANCIPATION - IN ADDITION

TO THEIR OWN LIBERATION WHEN FIRST JOINING THE LTTE. with Sita, a "Tamil Tigress," the anthropologist learns that for Sita - and many other female LTTE combatants - "it is enough to fight for liberation (vidutalai) and happiness of the people for the people". ${ }^{33}$ As a result of Sita's "absolute" attainment of personal liberation, she says that her mind and heart have also changed. She declares: "I have become even more ready to die. I see the suffering of the people and I have no fear about fighting and dying for them." ${ }^{34}$ Women like Sita yearn for the life of a fighter, and the honor earned by fighting for the people and her homeland (eelam). In addition to the privileged degree of physical power and mobility that she gained from training with the LTTE, she was "liberated from the helpless rage expressed in the laments of so many traditional Tamil women." ${ }^{35}$ Sita proved to the LTTE that she loves Tamil Eelam and is willing to die for her homeland; it is through this self-sacrifice that Sita, along with many others, achieved her own self-empowerment.

$$
\begin{gathered}
\text { WhO ARE FEMALE LTTE COMBatants? } \\
\text { WOMEN AS VICTIMS }
\end{gathered}
$$

The emergence of female combatants in the LTTE, however, has also prompted great debate about the victimization of women soldiers. Conservative Tamils who argue against the role of women militants often believe that females who join the fight have been manipulated and are defying Sri Lanka's socio-cultural norms. Some human rights activists perceive their involvement as a "support service, an instrument in the leadership's armour". ${ }^{36}$ Although many of these opponents provide compelling reasons to sympathize with the female fighters as victims of the LTTE, I believe that many women's roles as combatants against the oppressive state provided them with the means to actively empower themselves.

During the early stages of the war, it was quite common for the LTTE to target schools and villages in hopes of luring women into joining their cause. A young female soldier at the Methsevana Government Rehabilitation Center for Girls in Nugegoda recalls the LTTE's manipulative recruitment methods and how she became trapped in a life of fighting. She says: When I was sixteen the LTTE came to school and showed us war movies. Before that, they showed us karate videos. That's why I wanted to join for the karate. At first I liked it the training, the uniform, the weapons. I didn't learn karate but I learned how to shoot, and I enjoyed firing a weapon ... After a while, I realized how much I missed my family, and I felt such loneliness, I cried every night. But we couldn't go home ... It was a one-way door; you could go in, but you couldn't go out. ${ }^{37}$ 


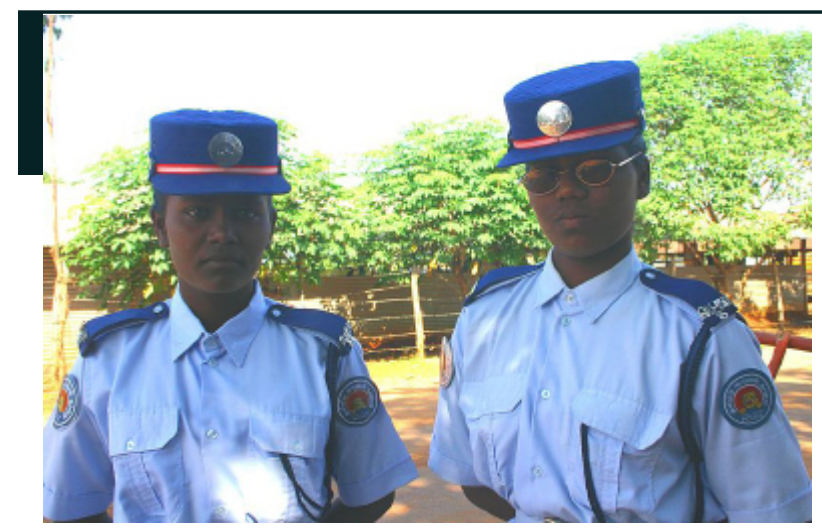

VARN PARTICIPATED IN

VARIOUS DIVISIONS OF THE

LTTE INCLUDING THEIR

POLICE FORCE

As the young combatant's accoun exemplifies, the LTTE employed a variety of methods to bring young soldiers into their ranks. A Tamil Catholic priest, Father Sebastian, explains how the LTTE "don't drag children out of their homes, they don't coerce them, but they do entice them. They [mostly] join voluntarily." 38 Newspaper and television accounts of young female members of the LTTE depict individuals who are "fanatically devoted to Prabhakaran" and who will "die for their homeland." ${ }^{39}$ These young, impressionable girls did not initially see past the initial allure of fighting for their nation. The notion that they might be able to escape their constrained lives and enter an exciting and "cool" adventure appealed to many Tamil women. ${ }^{40}$ Others were drawn to the fighting because of the more practical reason of the LTTE's pledge to provide security against the Sri Lankan army. ${ }^{4}$ Regardless of their reasons for joining, the majority of women did not realize how they would subsequently be bound by their choice to enlist. If they did join, they could not leave; it was a "one-way door," as those trapped behind it described their situation. These individuals, both women and men alike, renounced their childhood through the very act of joining the LTTE. The LTTE sought to lure young soldiers in, through any means necessary, in order to secure more fighters for the movement.
One might also argue that the LTTE victimized its female soldiers by using them merely as a means to achieve the ultimate goal of an independent homeland. Adamant opponents of the LTTE, such as Radhika Coomaraswamy, have even gone so far as to describe the female soldiers as "cogs in the wheel" of male leadership of the LTTE. ${ }^{42}$ Critics of LTTE female mobilization see these women as victims of the Prabhakaran's patriarchal nationalist project as well as the Sri Lankan military's oppression. Christine Sixta argues that female fighters are caught within the "triple bind of oppression": simultaneously battling Western oppression, societal [the state's] oppression, and internal oppression within their own insurgent groups. ${ }^{43}$ Most notably, as a result of this "patriarchal containment" within their chosen militant groups, women enjoy only "agentive moments in an interregnum where normalcy is suspended and there is license to transform taboo and social convention." ${ }^{44}$ These moments exemplify the LTTE's initial reasons for recruiting female soldiers. Female combatants such as members of the Black Tigers - a largely suicide bombing division of the LTTE - were used as exploitable resources. ${ }^{45}$ The LTTE profited from the fact that many women such as the infamous Dhanu the Black Tiger responsible for the death of Indian Prime Minister Rajiv Gandhi in 1991were willing to sacrifice themselves for the liberation of the Tamil people. ${ }^{46}$

Despite these arguments critiquing the militarization of females in the LTTE, I believe it is difficult to deny the first-hand accounts of self-empowerment and liberation by female soldiers. Although the LTTE did, at times, utilize deceitful methods of recruitment, those who enlisted were nevertheless motivated by a desire to either help their homeland or better themselves. Some research shows that even in cases of forcible recruitment, level of participation were better explained by the impact of the Sri Lankan state's repression on women's political ideals than by how they were recruited. ${ }^{47}$ It is true that the LTTE recruited it soldiers with the pragmatic and instrumenta aim of strengthening its army and fighting for an autonomous homeland. However, it is also important to note that many of the women who voluntarily or coercively joined the army, were ultimately driven by dual aspirations: to emancipate themselves as women as well as by their hopefulness and determination to secure greater power for the Tamil population as a whole.

If one looks at first-hand accounts by female soldiers, it is clear that these women envisioned a Tamil emancipation - in addition to their own liberation - when first joining the LTTE. For example, in her persona diary, Dhanu conveys her duty as a Tami individual to liberate her people. She writes: "the most important liberation struggle was the struggle for Eelam and the liberation of the Tamil people." 48 Thus, the LTTE's figh against the state symbolizes more than jus self-empowerment for those women engaging in combat: it is a chance to emancipate all $\mathrm{Sr}$ Lankan Tamils.

Those who argue that women such as Dhanu were merely a means to an end for the LTTE fail to acknowledge the personal benefits that the LTTE enabled many of its militants to gain. Most importantly, females fighting the public sphere were able to attain a sense of liberation that might have otherwise been impossible to achieve in the domestic sphere For many women, this liberation came in the form of emancipation, and extended freedom and mobility in their everyday lives. The LTTE's construction of new gender roles for the women provided them with the opportunity to envision identities beyond their domestic duties, and to actively contribute to the fight for a homeland. The "conservative feminised ideal is now a public figure engaged in masculine activities and repudiating patriarchal norms of womanhood." ${ }^{\prime 9}$ These women yearned for the life of a fighter, in order to break through the deeply-rooted hierarchical gendered structure of society. Tamilini, head of the women's political wing in the Sri Lankan postconflict processes, proclaimed: "Now there is acceptance of the LTTE women as equal within the movement." ${ }^{\circ 0}$ It is clear that many women also greatly benefited from the LTTE's services, such as military and leadership training. Such training and fighting in the battlefield provided numerous women with the strength and self-empowerment to defend their equality and fight for their homeland.

Additionally, joining the LTTE provided women with the practical skills and means needed to protect themselves. Balasingham writes: "Young women demanded their right to self-defense and their right to exercise their patriotic sentiments." ${ }^{51}$ The LTTE leadership expressed its commitment to the emancipation and equality of women and welcomed such demands by expanding its military program for female combatants. Margaret Trawick's research on why girls joined the LTTE revealed the shared belief that they were safest in the company of their LTTE brethren. One female combatant, Nalini, stated: "there is no fear in the jungle." ${ }^{52}$ The LTTE protected her from the Sri Lankan army while in the jungle and provided women like her with the necessary means to defend themselves - namely, AK$47 \mathrm{~s}$ and T56s. Without the LTTE, these 
women might be living in constant fear, and

heir lives would likely be severely limited y the conflict. Instead, they became active agents of their own survival, strength, and empowerment.

\section{CONCLUSION}

Although the Sri Lankan Civil War has left thousands of Tamil women in a position of helplessness and vulnerability at the hands of the state, there are many others who grew stronger and more empowered as a result of their participation in the violent and decadeslong conflict. Today, in post-war Sri Lanka, this newfound sense of inner strength and empowerment has radically shifted the way that many Tamil women approach everyday life and societal issues. As militarization post2009 reaches extreme levels, many Tamil women face a "desperate lack of security" and continue to "live in fear of violence" from the state (International Crisis Group i). ${ }^{53}$ Although many ex-female combatants continue to face economic constraints, limited mobility, and imminent displacement by the state, their experience in the war led to the reconstruction of gender identities and subsequent empowerment. These women were, in turn, able to cultivate high levels of commitment to a violent resistance movement and a nationalist cause. ${ }^{54}$ The issue remains, however, that enduring militarization under the Sri Lankan government continues to dictate what avenues are available to them and whether or not they will ever feel secure again.

Considering how recent this phenomenon of post-war militarization policy is, there is still a considerable amount of research needed to fully grasp the social and psychological impact of state militarization. On the one hand, Tamil activists have used this militarization in instrumental ways to further delegitimize the Sri Lankan state. Political analysts, on the other hand, continue to monitor the state's activity in the northern and eastern Tamil provinces, in hopes of preventing the recurrence of violent conflict. ${ }^{55}$ Until the state acknowledges the oppressed situation of these ex-combatant Tamil women and takes action to address it, there will always be a "latent potential for a resurgence in violent forms of resistance - particularly amongst Tamil women." 56 These female fighters' experiences fighting in the Civil War enabled may to attain personal liberation and continues to fuel their

desire to liberate the Tamil people.

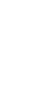

\section{U.S. POLICY OF Engagement tOWARd}

NORTH KOREA

NORMALIZING THE BALANCE OF TERROR

JUNG - JU LEE Cornell University
$T$

INTRODUCTION

he balance of terror created by on (WMDs) on the Korean peninsula has escalated the sense of uncertainty in East Asia,jeopardizing both the region's security and progress towards political and economic cooperation. The persistent efforts of North Korea in the development of nuclear weapons present a blatant challenge to the United States' strategic leverage in East Asia, international hegemonic influence, and global disarmament and nonproliferation initiatives. In this paper, I outline and evaluate three approaches to addressing the international threat posed by North Korea: 1) Hostile isolation through economic sanctions, intimidation, and aggressive military posturing to instigate denuclearization 2) Containment by impeding vertical and horizontal proliferation of North Korean missiles that emphasizes the maintenance of status quo over a policy of denuclearization 3) Engagement through multilateral efforts to offer political and economic incentives in exchange for gradual dismantlement of nuclear weapons production, backed by guarantees of international retaliation for failure to reciprocate. I essentially argue that isolation and containment measures have already been tried by the previous administrations and ultimately failed to secure cooperation or denuclearization because they refused to recognize nuclear weapons as the silver bullet to ensuring the regime's survival. Thus, resolving regional instabilities entails the pursuit of a strategy of engagement and gradual normalization over an extended timetable that precedes a policy of denuclearization through economic incentives in exchange for gradual denuclearization. Consequently, dismantlement becomes a process of weaning North Korea from its military dependence on nuclear weapons for survival to economic dependence on the international community, the sustained contact leading to greater transparency and interaction with international norms.

\section{UNDERSTANDING THE SECURITY} D I LEMMA

The nature of the North Korean threat fundamentally stems from transformative changes in the international system over the last half century that has resulted in a regional imbalance of power unfavorable to North Korea. In an international system of anarchy, the capabilities and intentions of surrounding states remain unclear. While this uncertainty of the capability of states and the certainty of the outcome of nuclear war in the form of mutually assured destruction sustains the logic of nuclear deterrence, it simultaneously obfuscates the ability to distinguish "offensive from defensive capability, which lie[s] at the core of [...] the "security dilemma"' on the Korean peninsula 1 Conventionally viewed as an irrational aggressor, 